\title{
Taxonomic relations of Plagiomnium affine (Funck.) Kop. and P. elatum (B.S.G.) Kop.
}

\section{H. MAMCZARZ}

\author{
Department of Taxonomy and Geography of Plants \\ of the Institute of Biology,
}

The Maria Curie-Skłodowska University, Lublin, Poland

(Received: May 15, 1973)

\begin{abstract}
A taxonomic study of two species of Mniaceae family (Mosses) was made based upon the microscopic features of specimens from extensive collection in Northern and Eastern Poland. The examined species of the genus Plagiomnium are treated in accordance with the new bryological classification.
\end{abstract}

\section{INTRODUCTION}

There are four closely related species in the genus Plagiomnium Kop. sect. Rosulata (Kindb.) Kop. They are P. affine (Funck) Kop., P. elatum (B.S.G.) Kop., P. medium (B.S.G.) Kop. and P. rugicum (Laur.) Kop. The basic diagnostic characters of these species (with the exception of $P$. medium) were investigated by T u o mikoski (1936) and of all species of this section by Kop o n e n $(1968,1971)$. Formerly the taxonomy was based on "Bryologia Europaea". L in d b e r g (1868) did not distinguish $P$. affine from the North American P. ciliare (C. Mül.) Kop. The considerable similarity and distinct variability of the diagnostic characters makes recognition of specimens (especially those belonging to $P$. affine, $P$. elatum and $P$. medium) difficult. Koponen (1967) made biometric examinations of specimens of $P$. affine and $P$. medium from the same localities. In the present paper the taxonomic characters of $P$. affine and $P$. elatum are analyzed. The gametophytes of these species change easily in the changing habitat conditions in spite of a constant karyotype and chromosome number $\mathrm{n}=6$ (H e itz, 1942; Hol m e n, 1958; L ow r y, 1948; S i n o i r, 1950). 
The ecological requirements of both species and their occurrence in plant communities were also determined.

\section{MATERIAL AND METHODS}

Herbaria specimens from the same localities in different areas of Southeastern Poland were used for the investigations. These were specimens of diverse variability, sterile and more rarely with sporogonia. The microscopic measurements of the main parameters describing the diagnostic characters of leaves of $P$. affine and $P$. elatum shoots are presented in Table 1. K o p o n e n's method (1967) was used in order to make comparison of the two species easy. However, Ko p o n e n's parameters were not used, rather a series of measurements was made of the characters presented in Table 1, with omission of the angle between the crenation and the leaf margin, and the variable length teeth was expressed as the number of teeth at border formed by 1, 2 and 3 cells. Measurements of 20 sterile and 4 fertile specimens were made in order to determine the ratio of the length and width of central lamina cells in $P$. affine and $P$. elatum leaf. From each lamina 5 measurements of 5 randomly chosen cells were made (one central and four accompanying).

\section{RESULTS}

The measurements have shown that the main characters distinguishing $P$. affine and $P$. elatum concern the structure of the teeth, the rows of the leaf margin and the lamina cells. Using Davidson's diagrams (1947) this was found to be true for both fertile and sterile specimens. As the diagrams are very similar they are not given here. The leaves of fertile and sterile specimens of these species are eliptically oval, and only in P. elatum frequently emarginate at the tip descending long and broadly down the stem. The costa is basically similar in both species. The thickest costa was found in sterile specimens of $P$. elatum. The maximal width at the tip is $30 \mu$, in the middle $132 \mu$ and at the base $582 \mu$. The number of stereids is considerable. The cells of the ventral epidermis of the costa are distinctly thick-walled. The costa extends beyond the lamina in $P$. affine and $P$. elatum. However, in $P$. elatum the costa rarely extends as a thorn or ends at the tip of the leaf (Fig. $3 \mathrm{~b}-\mathrm{e}$ ). The shape and number of teeth was taken into consideration by many authors. Both characters are variable, but differ in the two species. Measurements show that the number of these on both sides of the lamina is variable (Table 1). 
Table 1 The results of the measurements. The minimum, maximum, and mean values of the characters measured.

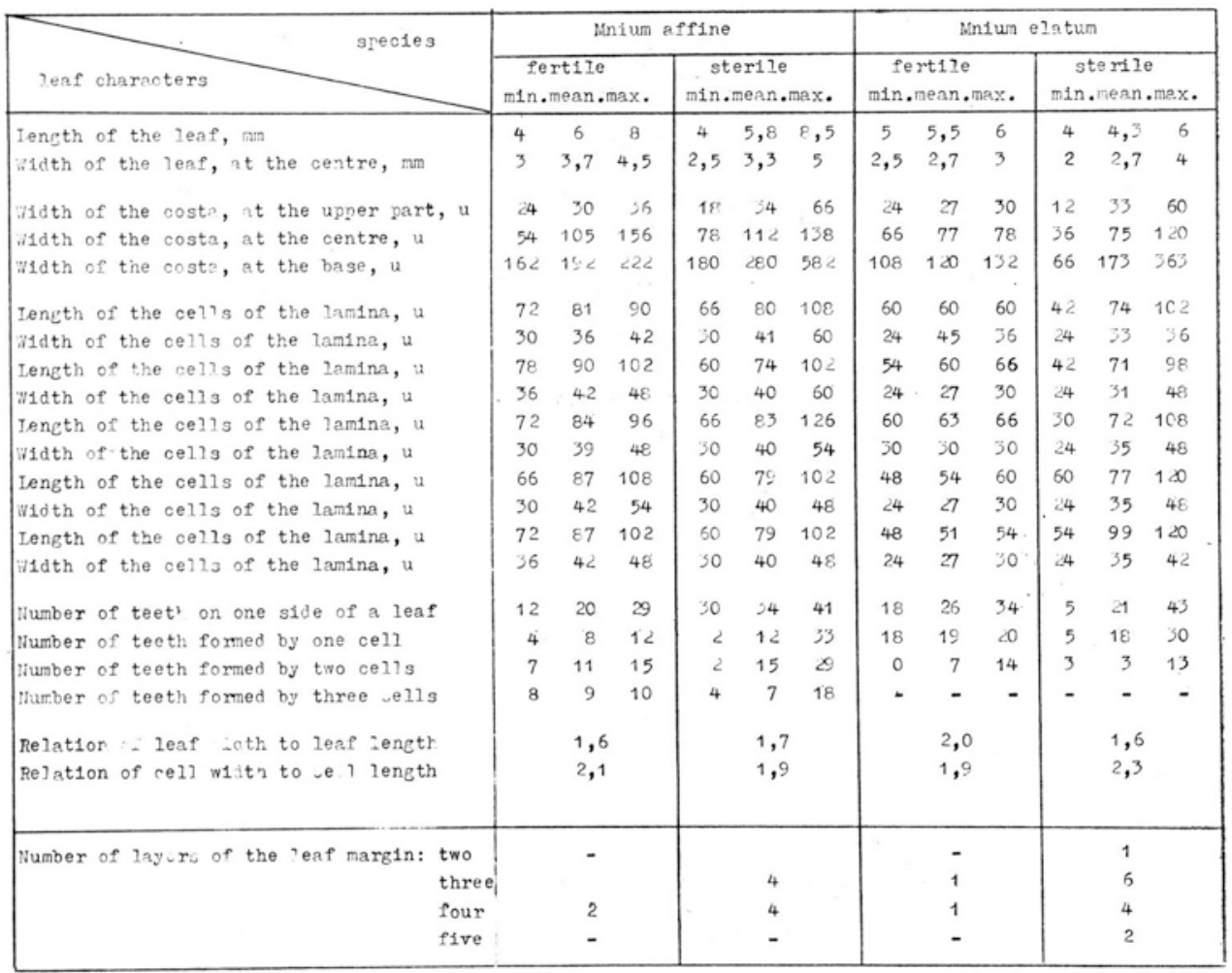

The leaves of $P$. affine in general have teeth composed of 2 or 3 cells and only few are formed by 1 cell. In $P$. elatum teeth in general consist of 1 cell or of 2 cells set on 1 large cell. In sterile specimens frequently only 5 teeth were found on one side of the leaf. In the apical part of the lamina the teeth are rudimentary or absent. Almost all leaves of $P$. affine are narrow near the base and on fertile stems extend low and narrowly down the stem. The length of teeth varies and the number of cells in the teeth does not depend on its length. $P$. affine and $P$. elatum even have short teeth consisting of 2 cells. Sometimes one-cell teeth at the leaf apex of the first species are short and stick out and in the second species are blunt and perpedicular to the leaf border. Frequently teeth of 2 and 3 cells are placed alternately on one side and the distances between them vary (Fig. $1 \mathrm{a}, \mathrm{b}$ ). The greatest number of teeth was found on sterile specimens of $P$. affine. The leaf margin is wide, but the number of layers varies. In $P$. affine plants in Poland the leaf margin has $3-4$ layers in both fertile and plagiotropic shoots. Margin with 5 layers have often been observed in sterile shoots (Fig. $2 \mathrm{~d}, \mathrm{e}$ ). Sometimes the first external layer is composed of large and fairly wide cells. Their teeth are formed by 1 or 2 cells. The 


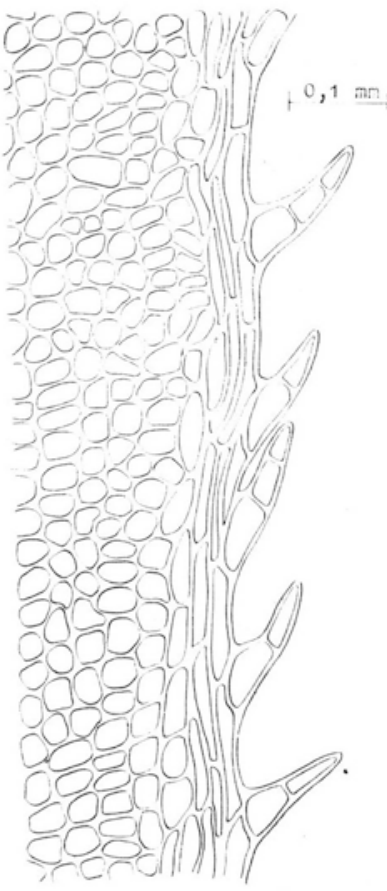

$a$

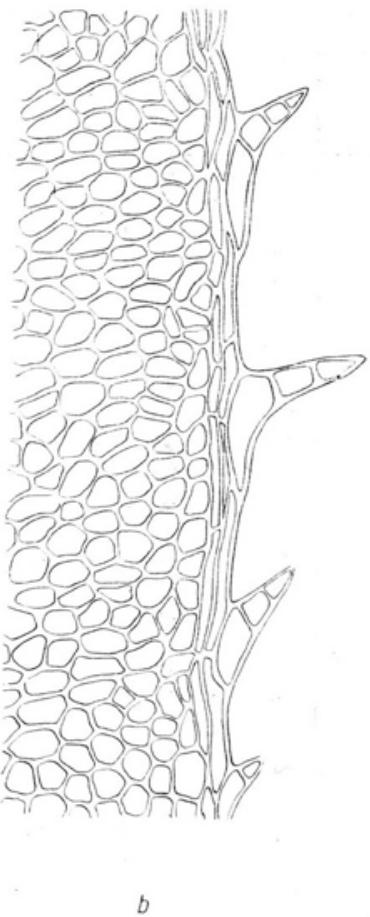

$b$

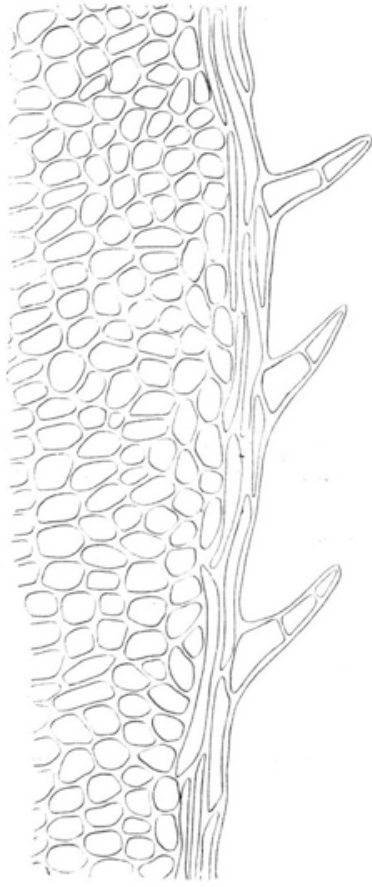

$c$

Fig. 1. Leaf margin at central part of leaves of Plagiomnium affine a - fertile; $b$ and $c$ - sterile

areolation of the lamina is similar as in other species of the section Rosulata. However, such species as $P$. affine, P. tezukae (Sak.) Kop. and $P$. ciliare similarly as $P$. elatum have elongated oval-polygonal central cells of the lamina (Fig. $4 \mathrm{a}, \mathrm{b}$ ). The ratio of length to width of the lamina of leaves of sterile and fertile specimens is presented on a diagram (Fig. 5) and shows minimal deviations in both species. These deviations are not as large as those observed by Koponen (1967) in his biometrical analysis of $P$. affine and $P$. medium. Due to the small differences between $P$. affine and $P$. elatum the latter species has been treated by many bryologists as a variety of the first (see Koponen 1971, p. $330-331$ ). The cells are arranged in fairly or very distinct arcuate layers symmetrically on both sides of the costa. The arcuate arrangement of cells is especially distinct in P. elatum. At the base and the apical part of leaves the cells are hexagonal and wider. Differences in the shape of cells in the apical part of leaves of both species are distinct and constitute another distinguishing character (Fig. 3 a-e). Only outer cells of leaves of P. elatum are elongated and 


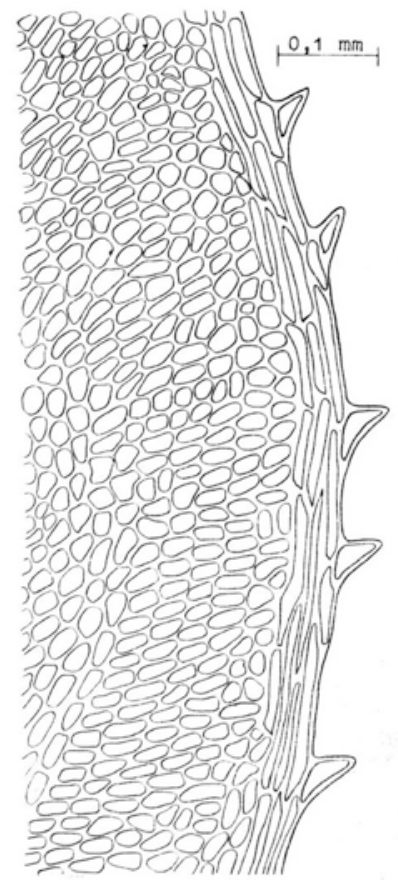

a

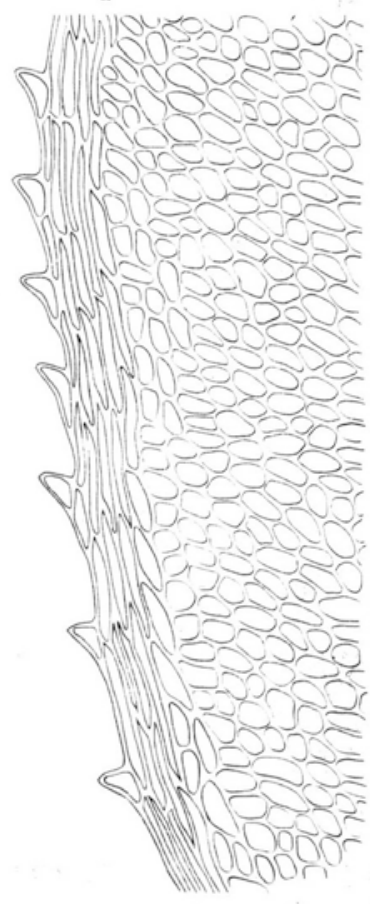

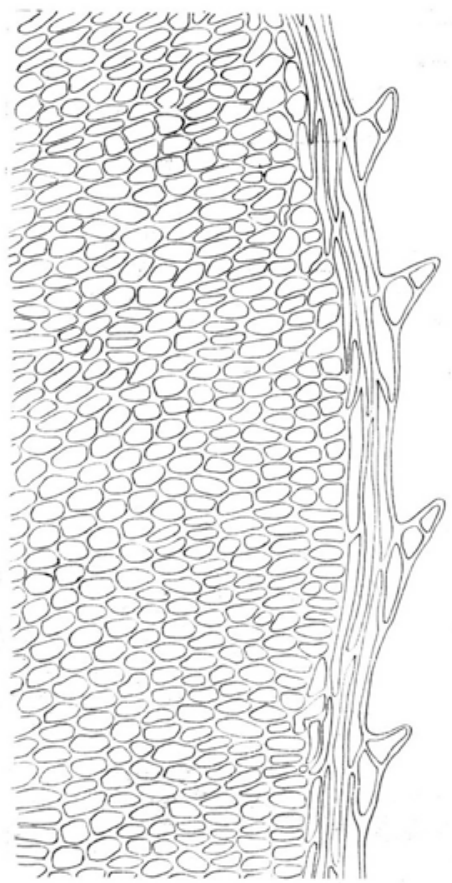

b

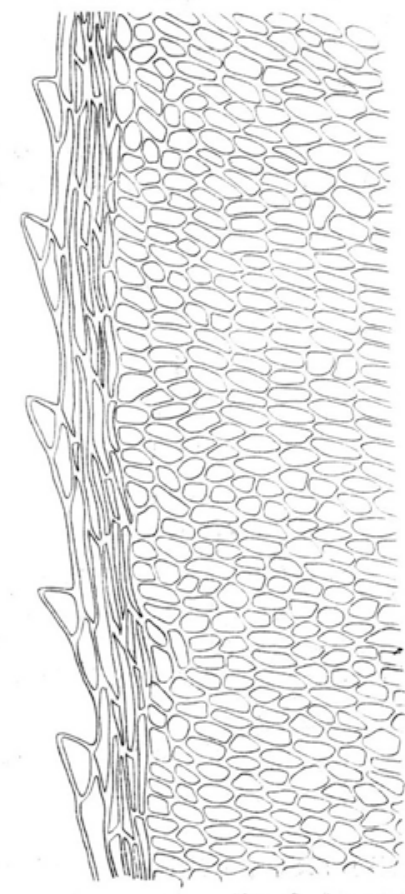

$e$
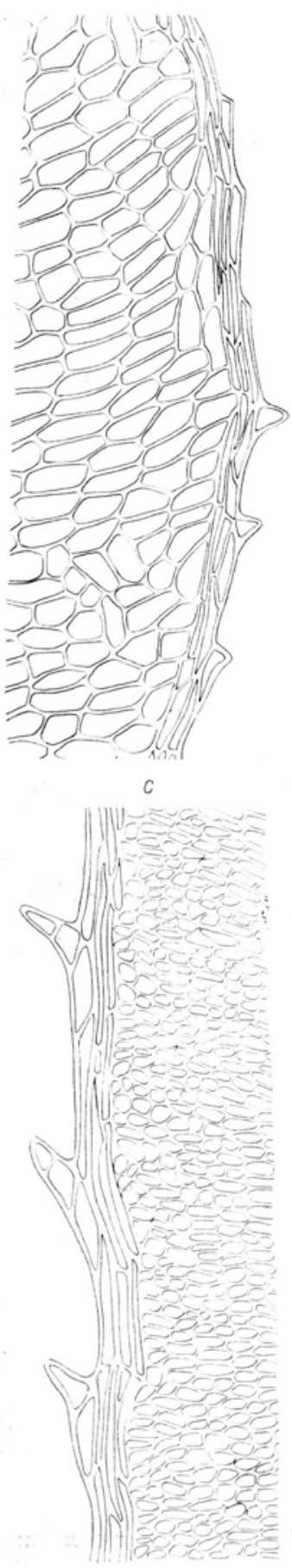

$f$

Fig. 2. Leaf margin at central part of leaves Plagiomnium elatum 

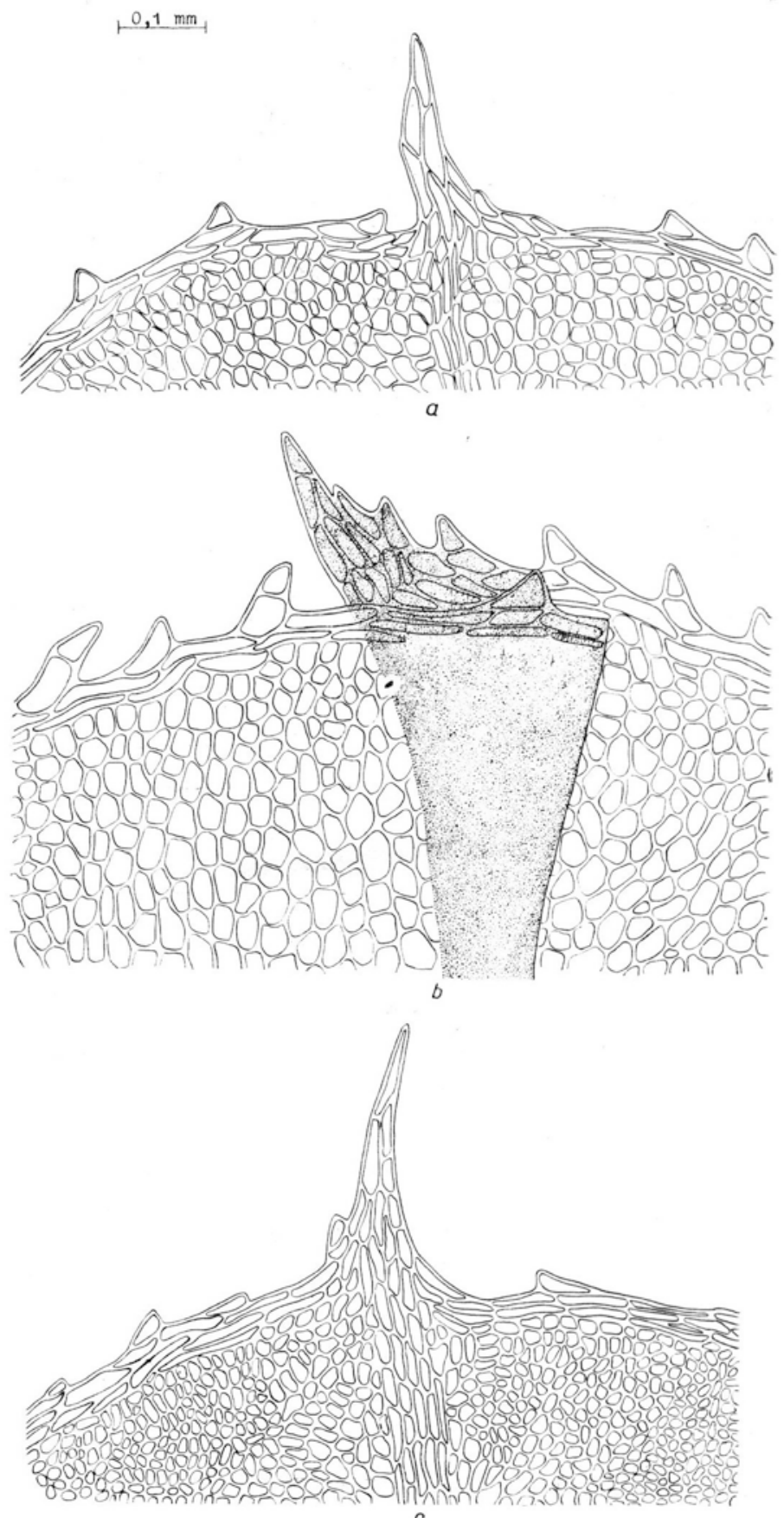

Fig. 3. Leaf apex on sterile stems of Plagiomnium affine $(a, b)$ and $P$. elatum $(b-d)$, and fertile stems of $P$. elatum $(e)$ 

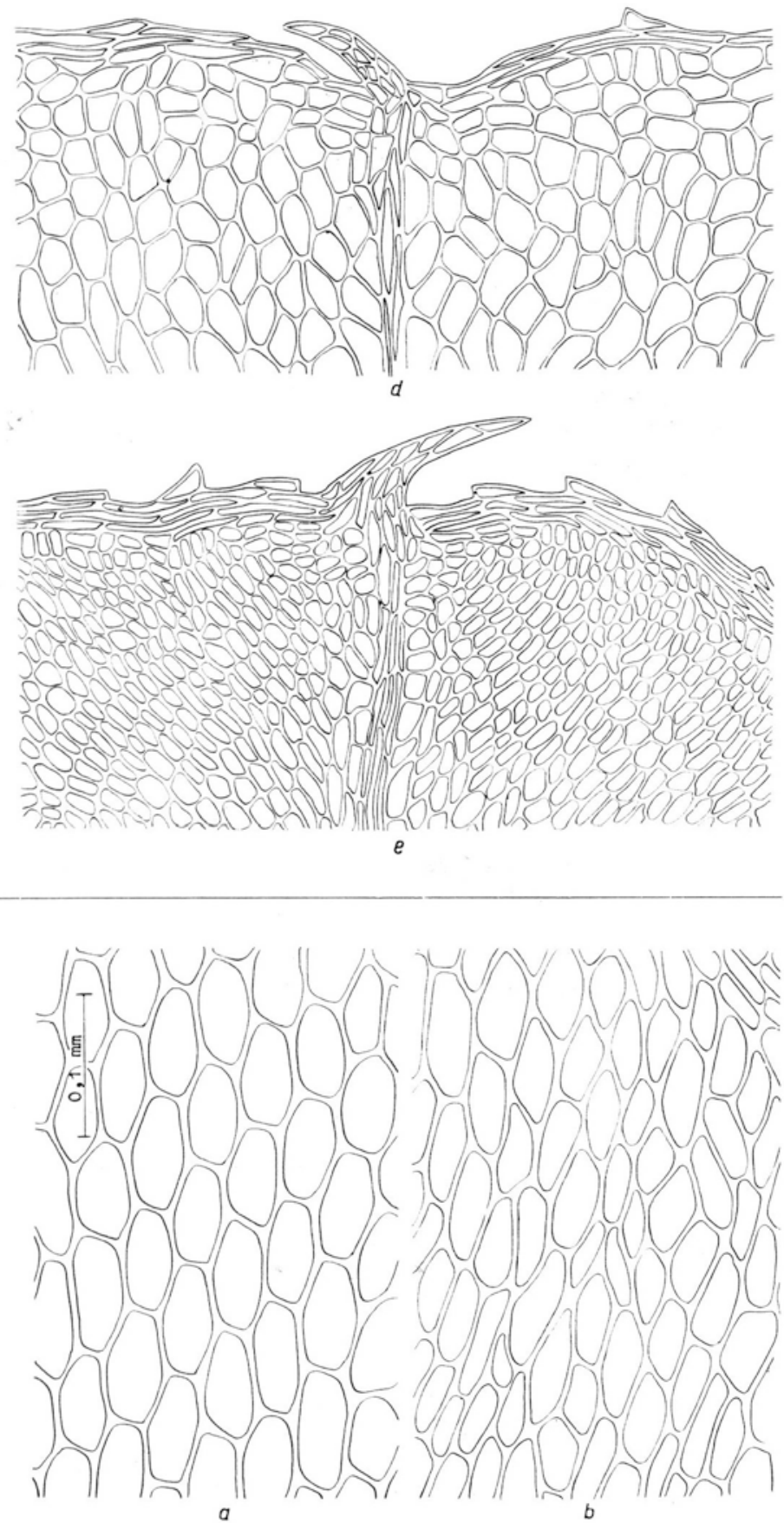

Fig. 4. Cells of central part of the lamina from the leaves of sterile stems of Plagiomnium affine (a) and P. elatum (b) 

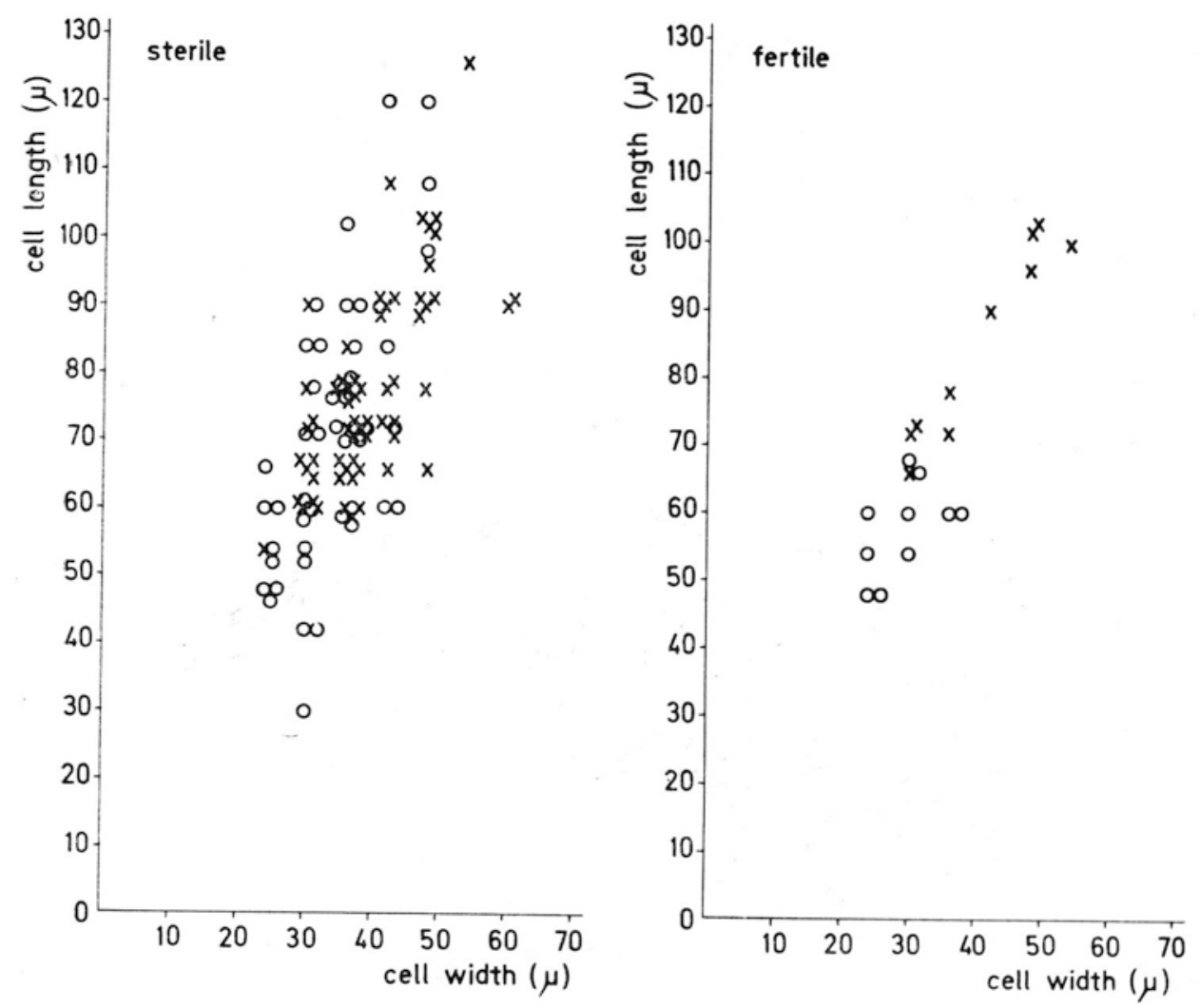

Fig.5. Diagrams showing the relation of cell length to cell width in lamina leaves of Plagiomnium affine $(x)$ and P. elatum (o).

reach the leaf margin perpendicularly (Fig. 2 b-c, e-f). The variation of the shapes of lamina cells is considerable, but similar in the two species. The ratio of length and width of cells in the central part of the lamina of sterile and fertile leaves of $P$. affine and $P$. elatum specimens shows very small deviations and cannot therefore be used as a diagnostic character.

\section{ECOLOGY AND DISTRIBUTION}

Plagiomnium affine often occurs in coniferous and mixed forests on an acid soil with dominance of pine, spruce and fir trees. It is common in humid and shaded decidous forests. In mountains it can be found in wet depressions and in shaded gorges (B u t te r f a s s, 1958; Koponen, 1968). In Polish phytosociological investigations the maximal frequency of occurrence of this species was found in 
associations with a dominance of coniferous trees: Piceetum fennoscandicum, Abietetum polonicum, Peucedano-Pinetum and Pino-Quercetum. It is also common on humid soil in the associations CircaeoAlnetum and Tilio-Carpinetum. It is oommon in West and Central Europe and in the mountains in these regions. If the soil dries out specimens of this species form numerous plagiotropic shoots. Gametangia and sporophytes are only formed on a paramently humid and shaded area.

Plagiomnium elatum grows mainly on eutrophic swampy meadows, reophilous peat bogs, marshy scrubs in river valleys and on the banks of lakes. It is numerous in boggy depressions with a well-developed layer of peat mosses in the associations Carici elongatae-Alnetum and Salicetum pentandro-cinereae. In boggy forests (Vaccinio uliginosiPinetum) it only grows in grassy places. On swampy meadows it is a comman component of two associations, Carici-Agrostidetum caninae and Caricetum gracilis. In Caricetum paradoxae it also occurs with Calliergon giganteum. J a s now ski (1962) found that P. elatum (described as Mnium seligeri) was frequent in the West-European association Juncetum subnodulosi in Szczecin Pomerania. In depressions and lake districts it grows on soil with a $\mathrm{pH}$ value 5-6 together with Plagiomnium rugicum. In turfs other mosses such as Calliergon cuspidatum, Drepanocladus aduncus, D. revolvens, D. vernicosus, Fissidens adianthoides are also common. On the banks of lakes and peat bogs on soil with a $\mathrm{pH}$ value 5.5 it grows together with Aulacomnium palustre, Calliergon cuspidatum, C. cordifolium, Camptothecium nitens and Sphagnum apiculatum. The greatest number of $P$. elatum stations can be found mainly in areas with considerable amount of rainfall and bogs, that is in Northern and Eastern Poland, and in swampy river vallyes in the lowland.

The two species grow together only sporadically in boggy mixed forests in Northeastern Poland, among others in Mazovia and in the Biebrza river basin.

I wish to tkank Doc. Dr. Ka z imierz $\mathrm{K}$ a r c z m a r z for critical remarks and advice in this work. 


\section{REFERENCES}

Bruch P., S chimper W. Ph. \& G ü m b 1 Th., 1938, Bryologia Europaea seu genera muscorum Europaeorum, Fasc. V, Bryaceae: Mnium: 4: 165-201.

Butterfass T., 1958, Mnium affine Blandow, ein häufiges meist übersehenes Moos Württembergs. Jahresh. Ver. vaterl. Naturkunde in Württemb. 113: $319-321$.

D a vidson J. F., 1947, The polygonal graph for simultaneous portrayal of several variables in population analysis. Madrano 9: 105-110.

Heitz E., 1942, Uber die Beziehung zwischen Polyploidie und Gemischtgeschlechtlichkeit bei Mossen. Arch. Klaus-Stift. Vererb. Forsch. 17: 444-448.

Holmen K., 1958, Cytotaxonomical studies in some Danish mosses. Bot. Tidsskr. 54: $23-43$.

J a s n ow s k i M., 1962, Budowa i roślinność torfowisk Pomorza Szczecińskiego. Soc. Sci. Stetin. 10: 1-339.

Koponen T., 1967, The typification of Mnium affine Funck and $M$. medium Bruch, Schimp. \& Gümb. Ann. Bot. Fenn. 4: 64-66.

$\mathrm{K}$ o p o n e in T., 1967, Biometrical analysis of a mixed stand of Mnium affine Funck and M. medium B.S.G. Ann. Bot. Fenn. 4: 67-73.

K o p o n e n T., 1968, The moss genus Plagiomnium Kop. sect. Rosulata (Lindb.) Kop. in northwestern Europe. Ann. Bot. Fenn. 5: 213-224.

K o p o n en T., 1971, A Monograph of Plagiomnium sect. Rosulata (Mniaceae). Ann Bot. Fenn. 8: 305-367.

L'i n d b e r g S. O., 1868, Observationes Mniaceis europaeis. Not. Sällsk. Fauna et Flora Fenin. 9: 39-88.

Lowry R. J., 1948, A Cytotaxonomic study of the genus Mnium. Mem. Torrey Bot. Club 20 (2): $1-42$.

Sinoir Y., 1950, Le type nucléaire et la mitose chez Mnium affine Sw. C. R. Acad. Sci. Paris 230: 2326-2328.

Sz a f r a n B., 1957, Mchy (Musci), Flora Polska, Rośliny zarodnikowe Polski i ziem ościennych, PAN, PWN, Warszawa, 1: 1-448.

T u o mikoski R., 1936, Über die Laubmoosarten Mnium affine, Mnium rugicum und Mnium seligeri. Ann. Bot. Soc. zool.-bot. Fenn. „Vanamo” 6 (5): 1-45.

Author's address:

Mgr Helena Mamczarz

Department of Plant Taxonomy and Geography

Institute of Biology, Maria Curie-Skłodowska University ul. Akademicka 19, 20-033 Lublin, Poland

\section{Taksonomiczne stosunki Plagiomnium affine (Funck) Kop. i P. elatum (B.S.G.) Kop.}

\section{Streszczenie}

Taksonomiczne cechy gatunków rodzaju Plagiomnium z sekcji Rosulata są bardzo zmilenne, a wyraźnie mogą być wykształcone tylko u typowych okazów. Badane gatunki - Plagiomnium affine i P. elatum odznaczają się wyjątkowo zmiennym zespołem cech struktury komórkowej liści łodyżkowych, mimo, że po- 
siadają jednakowe liczby chromosomów $(n=6)$. $\mathrm{Z}$ powodu występowania niewielkich różnic między nimi, niektórzy systematycy traktowali $P$. elatum jako odmianę $P$. affine. Główne cechy diagnostyczne obu gatunków, tak okazów sterylnych jak i tworzących gametangia i sporogony dotyczą wielu cech. Stały zespół cech taksonomicznych stanowią: długości i szerokości liści, szerokość żebra, długości i szerokości centralnej części blaszki liści, szerokość obrzeżenia blaszki oraz budowy ząbków. Ważny iteż jest tzw. współczynnik komórkowy określający stosunek szerokości do długości centralnych komórek blaszki liści łodyżkowych (tab. 1). W celu określenia współczynnika wykonano pomiary okazów sterylnych oraz tworzących gametangia i sporogony. Z każdej blaszki liścia wykonano pięć pomiarów, losowo wybranych 5 komórek (1 środkowej i 4 towarzyszących). Wyniki pomiarów opracowano według metody Koponen a (1967). Okazy do badań zostały zebrane ze stanowisk zwartego zasięgu i względnie dużej częstotliwości występowanila na tych samych powierzchniach $P$. affine i $P$. elatum na obszarze północno-wschodniej Polski. 